\title{
SPECII PROBLEMATICE PENTRU HERPETOFAUNA REPUBLICII MOLDOVA
}

\author{
Ţurcan Vladimir \\ Institutul de Zoologie, Chișinău, Republica Moldova, vladimirtsurcan@mail.ru
}

https://doi.org/10.53937/9789975315975.26

În rezultatul intensificării relaţiilor social-economice dintre diferite ţări și regiuni, dar și datorită factorilor climatici și impactului antropic, permanent se produc schimbări în caracterul răspândirii și distribuţiei multor specii de plante și animale, acestea fiind introduse conștient (sau nu) sau pe cale naturală în locuri din afara ariei lor. Nimerind în condiţii noi, unele specii se acomodează destul de bine, influențând diferit asupra faunei autohtone, astfel provocând schimbări și în comunităţile faunistice. Actualitatea cercetărilor în această direcţie este determinată de necesitatea cunoașterii și pronosticării schimbărilor care ar putea avea loc în comunităţile herpetofaunistice locale. În lucrarea dată sunt prezentate datele colectate pe parcursul studiului multianual referitor la răspândirea unor specii de amfibieni și reptile în apropierea hotarelor Republicii Moldova dar a căror prezenţă în fauna noastră rămâne discutabilă.

Relieful teritoriului cercetat si-a căpătat aspectul actual sub influența procesului de formare a munților Carpați si constituie o alternanţă de culmi, podișuri, depresiuni și culuare riverane care au condiţionat răspândirea spre nord a speciilor herpetofaunistice de stepă și pătrunderea spre sud a celor central-europene. Diversitatea herpetofaunistică este condiţionată de poziţia teritoriului la interferenţa a trei zone biogeografice: central-europeană - reprezentată de Podișul Central Moldovenesc; euroasiatică - de regiunile de silvostepă și stepă; mediteraneană - de fragmente de silvostepă xerofite din partea de sud. Atât componenţa faunistică și floristică, cât și aspectul landșaftic indică influenţa stepelor ponto-caspice, munţilor Carpaţi și peninsulei Balcanice. Majoritatea taxonilor herpetofaunistici sunt situaţi la extremităţile ariilor naturale ale 
lor, fapt ce sporește vulnerabilitatea lor faţă de factorii antropici. În limita spaţiului hidrografic Pruto-Nistrean trece periferia arealelor a 7 specii de reptile și 6 de amfibieni. După caracterul răspîndirii herpetofauna Republicii Moldova poate fi divizată în 4 grupuri:

Specii răspîndite pe întreg teritoriul Moldovei - Triturus cristatus, Triturus vulagris, Bufo viridis, Bombina bombina, Hyla arborea, Pelobates fuscus, Rana ridibunda, Rana escuilenta, Emys orbicularis, Natrix natrix. Aria acestor specii include tot teritoriul Republicii Moldova dar caracterul distribuției spațiale poartă un caracter neuniform (fragmentat) în dependență de starea habitatului și gradul de transformare antropică a terenului. Se întîlnesc în toate zonele naturale și subdiviziunile lor.

Specii cu răspîndire parţială - Rana temporaria, Rana dalmatina, Bufo bufo, Anguis fragilis, Lacerta agilis, Lacerta viridis, Podarcis tauricus, Natrix tessellata, Coluber caspius, Zamenis longisimus, Vipera berus. Răspîndirea parțială a speciilor date este determinată de amplasarea geografică a regiunilor fizico-geografice și a factorilor climatici.

Specii pe cale de dispariţie care necesită o atenţie deosebită în studierea stării lor: Elaphe sauromates, Vipera ursini, Eremias arguta. Declinul grav este determinat de reducerea considerabilă a sectoarelor de stepă și degradarea vegetaţiei prin pășunatul excesiv. Pentru evaluarea stării actuale sunt necesare investigaţii suplimentare orientate spre studierea detaliată a tuturor terenurilor cu aspect mai mult sau mai puţin natural, potenţiale pentru supravieţuirea acestor specii.

Speciile problematice formează un grup aparte deoarece prezenţa lor în fauna noastră rămîne discutabilă. Ariile lor se extind până în apropierea hotarelor Moldovei, dar pe teritoriul ţării nu au fost înregistrate populaţii viabile, fiind doar foarte rar găsite exemplare unice. Studiul caracterului actual al răspândirii și distribuţiei acestor specii ne arată că unele au pătruns în spaţiul dintre Nistru și Prut (Eremias arguta, Podarcis tauricus) relativ nu demult, iar altele (Lacerta muralis, Lacerta vivipara, Lacerta trilineata) și-au extins arealul pînă la hotarele Republicii Moldova 
datorită diferitor factori antropici și climatici. Datele, referitor la speciile care ar putea apărea în fauna noastră, au fost completate și datorită descoperirilor izolate și rezultatelor experimentale legate de reproducerea în condiţiile locale a speciilor de ţestoase Testudo graeca (cu areal disjunctiv, ocolind regiunea noastră) și Trachemys scripta (specie americană introdusă întâmplător).

O altă specie problematică este Salamandra salamandra întâlnită uneori în regiunea Podișului de Nord a Moldovei. Consider că exemplarele unice înregistrate pe teritoriul ţării noastre sunt întîmplătoare, acestea fiind aduse din regiunea premontană a Carpaţilor împreună cu torenţii de apă formaţi în timpul ploilor și inundaţiilor.

Așa dar, cercetările în teren și datele experimentale colectate, confirmă prezenţa populaţiilor viabile în apropierea hotarelor iar înregistrarea periodică a specimenilor unici și posibilitatea reproducerii în condiţiile ţării noastre a speciilor menţionate ne permit de a considera aceste specii ca elemente potenţiale pentru completarea herpetofaunei Republicii Moldova.

Studiul a fost efectuat în cadrul proiectului fundamental 15.187.0211F realizat în cadrul Institutului de Zoologie. 